\title{
STUDIES ON RELATI BETWEEN THE PNEUMATIC CELL SYSTEM OF THE MASTOID PROCESS AND AUDITION
}

By

\author{
F. SEI
}

\section{From the Department of Oto-Rhino-Laryngology Nagoya Univyrsity Medical School (Director: Prof. S. Goto)}

Study on the relation between the type of middle ear pneumatisation and tne threshold for air and bone conduction sound was made. It was difficult to estimate the threshold for air and bone cenduction sound by the study of the pneunatisation alone.

\section{側頭骨蜂窠の状態と聴力との関係}

\author{
名古屋大学医学部耳竄咽喉科学教室 (主任; 後藤修二教授)
}

蔳盗士 夫

\section{目次 \\ 第1章䌌言 \\ 第 2 章 研究材料及び研究万法 \\ 第 1 節 研究材料 \\ 第 2 節 研究方法 \\ 第 1 項 正常㙏力の判定 \\ 第 2 項 $\mathrm{X}$ 線像の判定}

第 3 音 奏験成綪

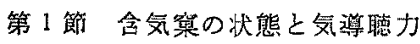

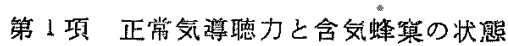

第 2 項 気導聴力の低下と会気蜂䆬の状態

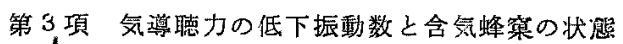

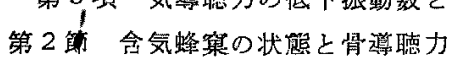

第 I項 正常骨導德力と含気蜂窠の状態

第 2 項 骨導聴力の低下と含気蜂檾の状態

第 4 項 骨導聴力の低下振動数と含気䗋窠の状態

第 5 項 骨導聴力の上年振動数と含気蜂笨の状態 第 4 章 縚括並儿考按

第 1 節 気導聴力と含気蜂穼との関係

第 2 節 骨道聴力と含気蜂然との関係

第 5 章 結 諭

参考文献

\section{第 1 章 緒言}

音の骨伝遒に側頭骨含気蜂集の状態が影響を及ぼすむ のではなかららか，若し影輴を及ぼしているのであれ
ば、それはどのようなるのであろら为，又影響を及ぼす ものとするならば正常骨導といらものも, 含気䗋巢の状 態を侤慮に入れなけ秃ばならないのではなからうか。

これ等の疑問を明らかにするため文献を造殍するに，

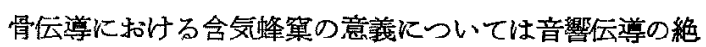
縁に効果汸あるという論説に原口，原田，Mac Donald， 恩地, 滰田等の矿究がある. 即ち原田は内耳の位置と含 気蜂窠の形態とから推して含気蜂㮤は内耳に対する音の 絶縁体ならんと述べ，Mac Donald，恩地は含気蜂菓は 骨導音の吸収室ならえと述べいずれる，その理論の主体 は含気蜂集が多くの胞腔の集団からなつており，これは 物里的に見て音響伝尊に效する不自尊体であるといらこ とによつているすのである.最近 Pullenは“骨遒にお ける乳椂突起の 絶緑効果”之題して 側頭蜂㮤の 発青度 のいかんと蜂窼胞の大小とによって骨導聴力に差異があ ることを証し，結論として骨導聴力の悪いといらことは 必ずしも聴神経障碍の現われではなく，大細胞性の乳 様突起は有力な音の絶緑であり，骨俱に対して $25 \mathrm{db}$ の損失を与え, 蜂柋発達のいかんによつても骨導に差異 を生ずるものであると述べている。 しかし，Pullenの 結果の如く音の骨導が乳様突起の蜂窂の状態によつて大 きな差暴があるものとする時は聴力検查に和ける骨導の 問題は再検討を要することになる，即ち，正常骨導聴力 が既に問題となるものであり，これを決定しなければ病 的㯖器の骨尊を云ヶすることは不可能であるからであ 
る.今こ、に正常骨尊聴力なる言語を用いたが現在いか なるものを正常骨導聴才として採用してよいかは間題で ある、即ち，骨導聴力では気遒愊力のよらに最小可聴閵 值 $(0 \mathrm{db})$ を正常骨導聴力と乙て採用することがむつか

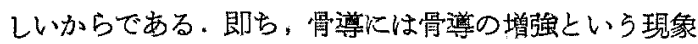
があり，正常の骨尊㯖力より良好な病的な骨導媤力が存 在するからである。㕛原口は 49-A オージォメー名一 を用いて跬耳及び病的耳の気導及び骨遒聴力を湘定しこ れと Schüller 氏斜位撮影法によるレ線写基を誖藤 (敏) の含気蜂案の分類法により分類したものと比較して, 含 気蜂察の過良型と両側抑制型との間に気導では著明な差 異を認めなかつたが骨遒では256万至 $2048 \mathrm{cps}$ に扣い て抑制型に $5 \mathrm{~d}$ b 内外の聴力增進を認めたとのべている. 又，後藤 (敏) は含気蜂笨の型態と骨伝尊の関係を調查 し，含気蜂笨の不良なるのでは骨伝尊は超長し，含気蜂 巢のよいものでは骨導が短縮すると述べて原口の結果と 同様の結論をえている、滝田は骨導或值变動と乳祿蜂罙 の発育度之の相関々係を探究して実駼的にも理諭的にb 抑制型が良好型より骨弹音に対する感受性が增進してい ること孝礁認している。

含気蜂窠と気導聴力との関係を論じたものに $\mathrm{Mac}$ Donald の害験がある. 即ら，特殊装置によつて乳橡洞 を中耳腔から隔離して場合としからざる場合との鼓膜の 振動状態を测定し，その結果，含気蜂窠は鼓膜後方にで

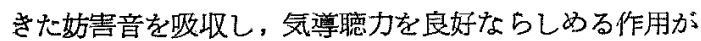
あると述べている，原口は音の吸収装置（中耳及び乳様 蜂菓) の有無が政膜の振動に与える影響を模型により实

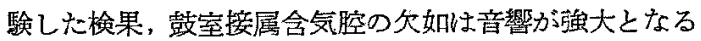
に従つて攱膜振動を障碍し，その振幅を娍少せしめて， その霆を增大せしめることを認め，これから推意して中

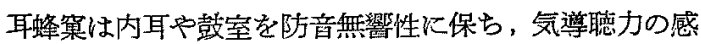
度と忠実度とを良好ならしめる作用があると述べてい る.

以上の諸文献を通じて共通していることは合気峰巢は 骨尊音に刘する絶縁体であり，含気蜂巢の発達している もの程音住する郊緑効果が大であるといらことである

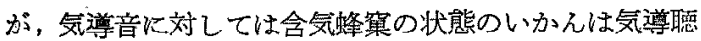
力に著明な差異を与党ないというるのと，著明なる差異 を与えるというるのっ二説に分れる。

こつた和いて私は側頭骨含気蜂窠の状熊と骨導聴力と の関係を探求すると共に気導聴力との関俰をる調べ, 前 生の側頭合気蜂窂と聴力との関係問題を解決しようとし た.

\section{第 2 章 研究材料及び研究方法}

第 1 節 邵宛材料

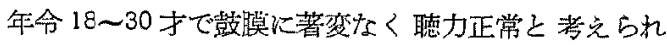

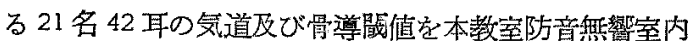
に衿て 49-A ォージォメーターにて湘定すると共に Sonnenkalb 斜位撮影法によつて側䫄骨の X 線写真を 撮影しこれ等の閶值と $\mathrm{X}$ 線像とを研究材料とした。

第 2 算 研究方法

第 1 項 正常楛力の半定

骨尊聴力は骨對娭查機具の瘇類及び検查方法等によつ て，その值に変化をきたするのである。そこで, 范分注 甞を払い常に一定の穼件のるとに䏇力検查を行らように 努めた、しかして聴力の半定に当つて間題になることは 骨学衈力の基準を何观に求めるかである.

Fowler は正常骨導聴力の決定は困難であるとのべ, その里由七して，年令により，又ホージォメーダ一の骨 導子の相異により闒值に変敒があることをあげている。 しかして，暏は Western Electric D-80904 Audiomer を用い, 気導 $256 \infty 17 \mathrm{db}, 10240012 \mathrm{db}, 4096012 \mathrm{db}$,

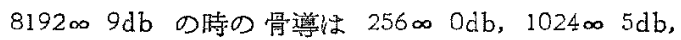
$4096008 \mathrm{db}, 819202 \mathrm{db}$ であるとい5，しかして，骨

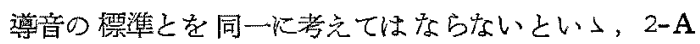
Audiome の正常骨望聴力は Odb をるつて表している

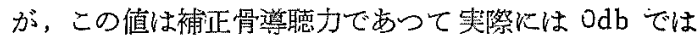
ないとのべている、このように骨畠聴力の基準をいかな る点に求めたら良いかについては非常に閣題である。し かし乍ら，臨床的には正常気尊德力を有するもの小骨導 聴力を正常とすべきであるう。

しかして本矿究の娰象とした者の気尊俧力は 49-A オージオメーターの全音域に亘つて $20 \mathrm{db}$ ⿺り度いわの であつたが，全音域 $10 \mathrm{db}$ 以内の気㮍恶力を有するすの を正常䏇力者とした，かくて，この正常気聴力を有寸る

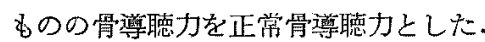

その 49-A ホージオメーターの全音戴に㫜つて 10db

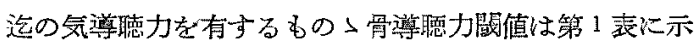
すようである。

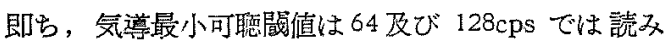
$5 \mathrm{db}$ を中心として $55 \mathrm{db}$ の贸国にあり，256cps では No. $4 \mathrm{R}$ の 1 例を除けば読み $5 \mathrm{db}$ を中心 $5 \mathrm{db}$ の 範国にあり，512cps では No１１，L，の2例を除けば

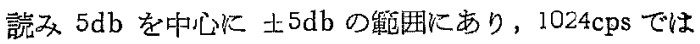
No. $1 \mathrm{R}$ の1例它除けば讜み $0 \mathrm{db}$ を山に士5dbの

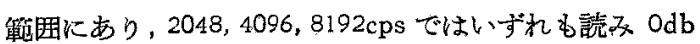




\begin{tabular}{|c|c|c|c|c|c|c|c|c|c|c|c|c|c|c|c|c|}
\hline & & & 揌 & $\pi$ & & \\
\hline & 64. & 128 & 256 & 5,2 & 1024 & 2248 & 109618 & 8192 & 64 & 128 & 256 & 512 & 1024 & 2048 & 199618 & 8192 \\
\hline $\mid R$ & 0 & 5 & 0 & -5 & -10 & -5 & 0 & -5 & 50 & 60 & 55 & 55 & 45 & 35 & 25 & 5 \\
\hline 4 & 0 & 5 & 5 & -5 & -5 & -5 & 0 & -5 & 40 & 60 & 55 & 55 & 45 & 30 & 30 & 0 \\
\hline$|R|$ & & 5 & 5 & 5 & 0 & 5 & -5 & 5 & 45 & 50 & 45 & 50 & 40. & 30 & 30 & 5 \\
\hline $\mid L$ & & 5 & 5 & 5 & 5 & 5. & 5 & 5 & 45 & 50 & 40 & 40 & 35 & 35 & 30 & \\
\hline & & 10 & 10 & 10 & 5 & 5 & 0 & 0 & 45 & 55 & 45 & 50 & 45 & 30 & $25-$ & -5 \\
\hline$L$ & & 10 & 10. & 10 & 5 & 5 & 5 & -5 & 45 & 55 & 50 & 45 & 45 & 25 & 25 & 10 \\
\hline$|R|$ & & 5 & & 5 & -5 & 5 & -5 & -5 & 45 & 50 & 50 & 55 & 45 & 30 & 30 & -5 \\
\hline 4 & 5 & 0 & -5 & 0 & -5 & 0 & -5 & -5 & 50 & 60 & 55 & 50 & 45 & 30 & 30 & 0 \\
\hline & & 5 & 5 & 5. & 0 & 5 & -5 & 0 & 45 & 50 & 50 & 50 & 40 & 25 & 25 & 5 \\
\hline L & 5 & 5 & 0 & 5 & 0 & 5 & -5 & -5 & 45 & 50 & 45 & 45 & 40 & 25 & 20 & 0 \\
\hline 图 & 5 & 5 & 5 & 5 & 0 & 0 & 0 & 0 & 45 & 55 & 50 & 50 & 40 & 30 & 25 & 0 \\
\hline 软 & & $n$ & $"$ & $\because$ & $"$ & $"$ & $"$ & 1 & \pm 5 & $"$ & $"$ & " & $" 1$ & $n$ & 1" & \\
\hline
\end{tabular}

を中心に士5db の雨因にある。しかもこ机らの例外も 僅かの差であり，闌值む小であるからこれ等を正常気導 聴力と判定して誤りないと涪える. 従つて, 本検查器其

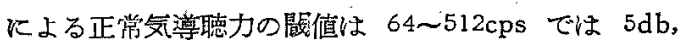
1024 8102cps では Odb を中心に $\pm 5 \mathrm{db} の$ 範囲内の ものと䜅定した。

しかして, 正常骨導恥力の判定を上述の正常気導聴力 者の骨導聴力からそのま〉決定すること〉した，從つ て，骨尊聴力の䦭值範国は $64 \mathrm{cps}$ では読み $45 \mathrm{db}$ を中 凹に $15 \mathrm{db}$ の範围にあり,128cps では読み $5.5 \mathrm{db}$ を中 凹に $55 \mathrm{db}$ の範四にあり，256cps では No. 2 Lの」 例を除けば読み $50 \mathrm{db}$ を心に $\pm 5 \mathrm{db}$ の範围にあり， $512 \mathrm{cps}$ もNo. 2L の 1 例を除けば読み $50 \mathrm{db}$ を中心 $\pm 5 \mathrm{db}$ の範囲にあり，1024cps では $40 \mathrm{db}$ を中心 $5 \mathrm{db}$ の範围にあり，2048cps では 30db を中心に 4096

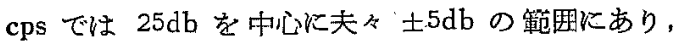
8192cps では No. 3L の1 例を除けば読み Odbをを心 に土5db の範围にある。

こ〉に执いて僅かの例外を除いて正常骨導聴力の閧值 は $64 \mathrm{cps}, 45 \mathrm{db}, 128 \mathrm{cps}$. $55 \mathrm{db}, 256 \mathrm{cps} .50 \mathrm{db}, 512 \mathrm{cps}$, $50 \mathrm{db}, 1024 \mathrm{cps}, 40 \mathrm{db}, 2048 \mathrm{cps}$. 30db, 4096cps. 25db, 8192cps. Odb を中心㚘々 $\pm 5 \mathrm{db}$ の範国内のbのと認 定した。

第2 項 $\mathrm{X}$ 線像の判定.

側頭骨含気蜂気蜂窠の状態を知る上に Sonnenkalb
氏斜位撮影法のみによる像では側頭骨全体の含気蜂窠の 発達状態を知ることは不可能であるのは当然であるが，

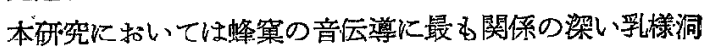
蜂巢の状態を检索するのか゚主眼である，従って，本撮影 法によつて概小その目的を迳することができる。

しかして，X 線像による 側頭骨蜂策の 状態の判定は 1）その含気度，2）胞腔の大いさ及び 3) 胞腔の排列状 態によつて区分した。

1) 合気度の分類は蜂案が迷路周囲, S 状洞周团側頭 磷錐体に広く及ふ心の含気度「甚大」とし，これより， その発達少しく軽度なるのび蜂窼群の.1つの発達が甚 た雳いものを含気度「大」としこれより更に含気蜂窠 の発達が全体に少しく軽度にして, 異状な蜂䆩群の発達 を諗めないるのを「中」とし，含気蜂黛の発達が悪く、 $\mathrm{X}$ 線像にて䗋笨が岩样骨三角内に执さする程度の発達を示 するのを合気度「小」とした。

2）胞腔の大いきは $X$ 線上大豆大以上のものが多い易 合を「大」とし, 小豆大乃至兴粒大のものが多い昜合を 「中」とし, 梠粒大以下文は各胞腔の 弁別不时䄞なるる のを「小よし，小胞腔が Aditus を中心に密在し，大 胞腔がその周辺に辺在しているすのを「温合性」とし $た$.

3) 胞腔の排列状態は胞腔が 孚漛洞より辺縁に到るに 従い漸次大となり，中耳腔に向つて胞腔か列んでいるも のを排列が「規則正しいるの」とし，これよりすや」不 規則なるものを「や〉規則正しいもの」とし，排列状態 の不鮮明なるものを「不規則」とした。

なお術後性のbのはrO.P」総てと記した。

\section{第3章 実験成績}

42 耳の Sonnenkalb 氏斜位撮影法によるX 線写真 像を含気蜂窠の状態かっら含気度と胞腔の大いさと排列状 態とによつて分類した成綘と 49-A オージーメーター

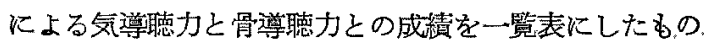
は第 2 表である。

しかして，第2 表の結果に乱いて，次の要領で愳力の 分類を行つた結果第3表に示すよらになる。

即ち，各々の周波数の気導聴力が正常気尊間值範囲内 にあるすのは総て $A^{\prime}$ で表わしこれより聴力の低下し ているるのは総て B

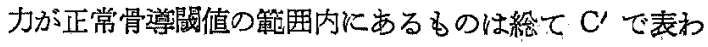

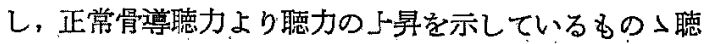
力は総て b'で，低下を示しているもの〉㯖力は総て c で表わした．更に各症例の聴力の判定は気導では全 
第 2 表 含気蜂窂の状態と聴力像

隺 $d b$

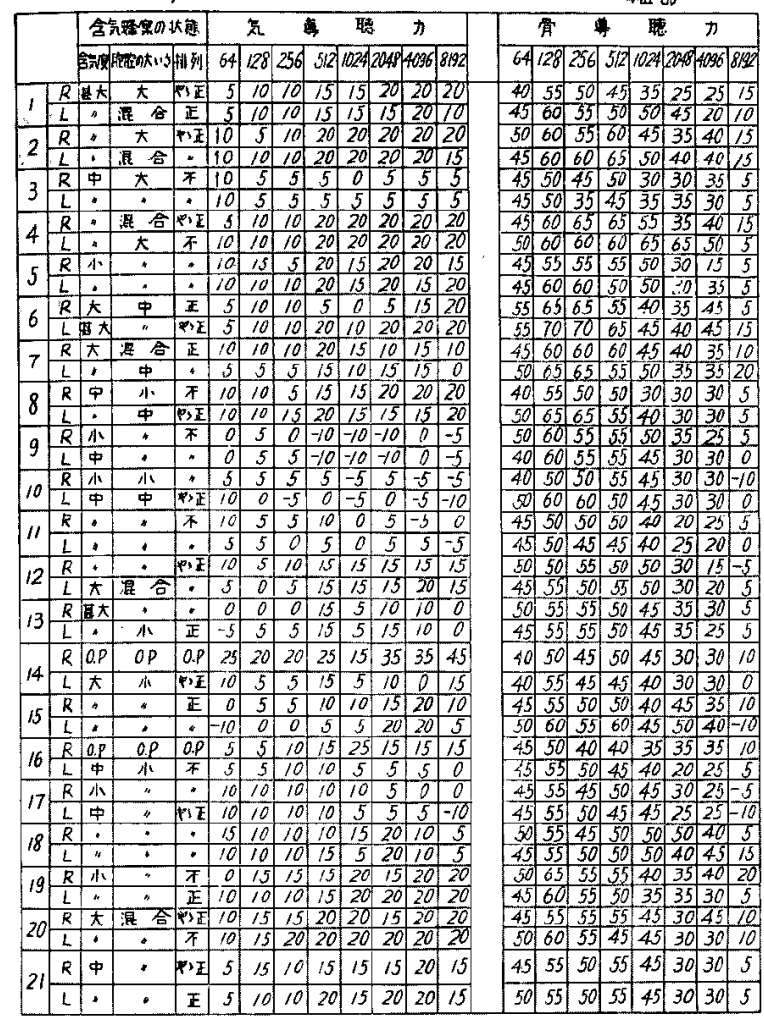

第 3 表 会気蜂勧及び聴力の分頪成程

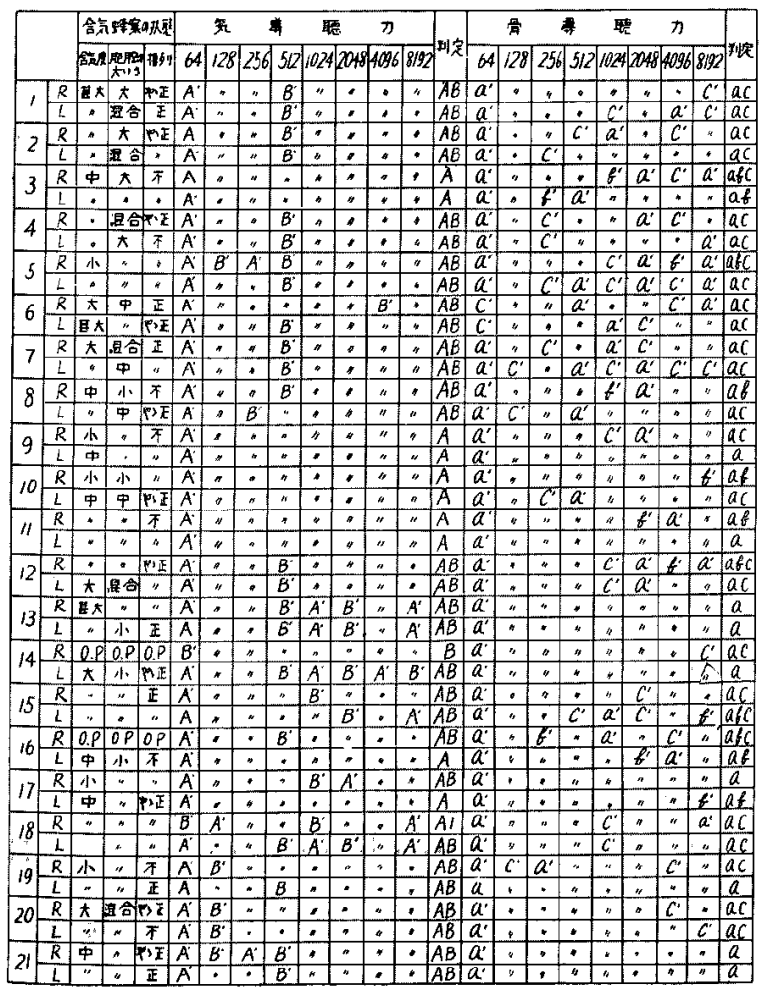

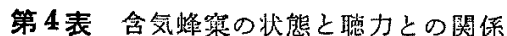

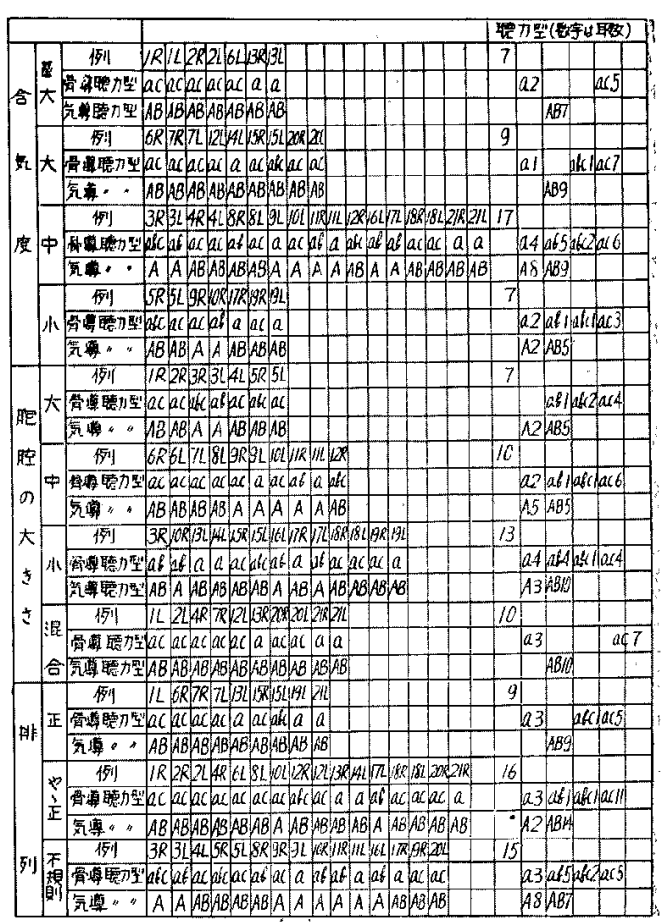

第 5 表 含気峰窼の状態之骨導聴无 低下又は上界との関係

(合計O影宇生C数)

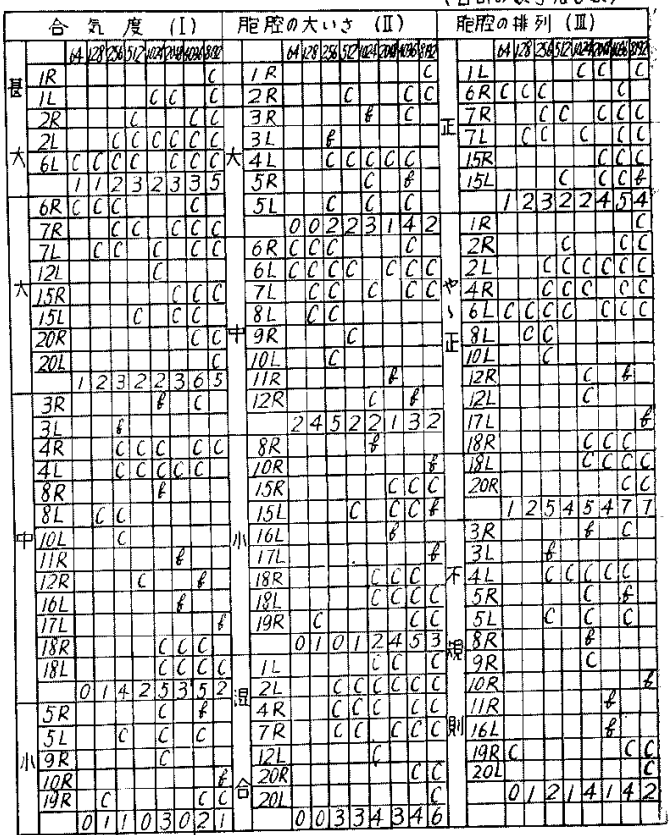


谙域の㯖力が総て $\mathrm{A}^{\prime}$ なるものを $\mathrm{A}$ で，総て $\mathrm{B}^{\prime}$ なる ものを $\mathrm{B} て ゙, \mathrm{~A}^{\prime}$ と $\mathrm{B}^{\prime}$ が混在しているすのは $\mathrm{AB} て ゙$ 表わし，骨導では全音域の聴力が総て $\mathbf{a}^{\prime}$ なるものをa

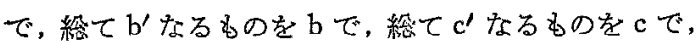
$a^{\prime}, b^{\prime}, c^{\prime}$ が混在しているものは夫々 $a b, a c, b c, a b c$ 等 で表わした。

そこで，第 3 表の聴力の分類成漬と先の含気蜂翼の分 類成績とを表に組めると第4 表に示す上らになる。

第 4 表の気導及び骨導婹力の分類の内，正常骨導及び 正常気奪聴力を示さないるの〉内容, 即ち, いかなる音

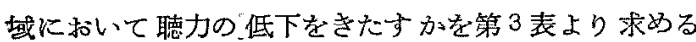
灶，第5表，第6表沶与上らである。

第 6 表 含気蜂菑の状態と気導聴力低下との関俰

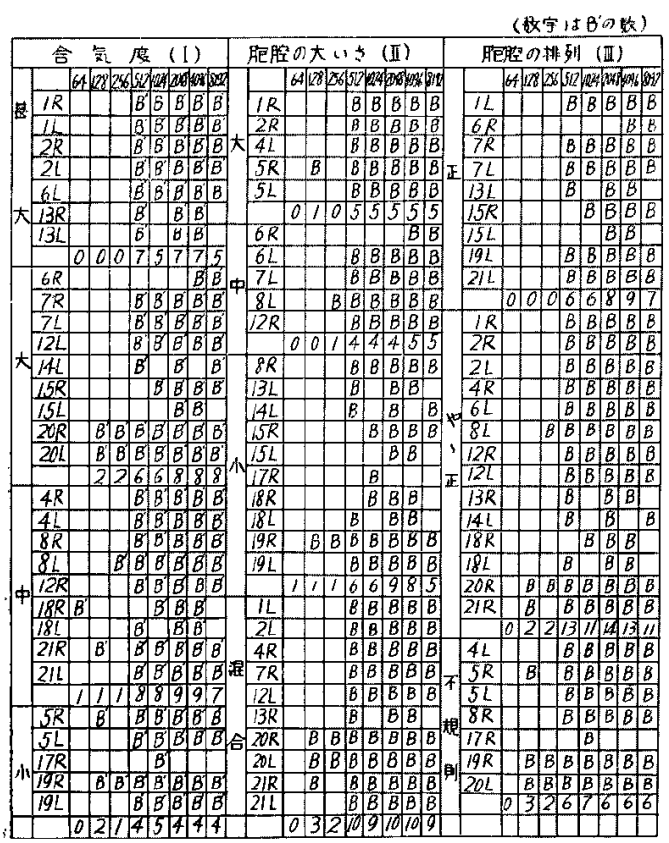

第 1 節 含気蜂巢の状態と気導聴力

第 1 項 正常気導聴力と含気蜂窠の状態

1) 含気度と正常気導聴力

第4 表より，含気度甚大なるるの及び含気度大なるる のに怔常気導聴力を示するのはなく，含気度中なるむ の 17例中には 3RL, 9L,10L,11RL, 16L.17L の8 例 (47\%) があり，合気度小なるもの7例中には $9 \mathrm{R}, 10 \mathrm{R}$ .の 2 例 $(29 \%)$ がある。即占，含気度中なる るの約 $1 / 2$ は正常気導聴力を示すが含気度小なる るのでは約 11/3にあるのみであり，含気度甚大なるすの及び含気度
大なるるのにはない。

2）胞腔の大いさ之正常気導聴力

正常気導聴力を示するのは腔膑の大いさの大なるるの 7 例中 3RL の2 例 (29\%) であり，胞腔の大いさの中 なるむの 10 例中 $9 \mathrm{RL}, 10 \mathrm{RL}, 1 \mathrm{RL} の 5$ 例 (50\%) で あり，胞腔の大いさ小なるもの例中 10R，16L，17Lの 3 例 $(23 \%)$ であり，胞腔の大いさ混合性なるるの小 10 例中にはない，即ち，正常気導婹力を示すむのは胞腔の 大いさの中なるものに最も多く，次に大なるものと小な るもので, 混合性のものには認められない。

3) 胞腔の排列と正常気導聴力

胞腔の排列の規則正しいるの9 例中Kは正常気導㯖力 を示するのはなく，胞腔の排列のや〉規則正しいもの 16 例中には 10L，17L の 2 例 (13\%) があり, 胞腔の 排列の不規則なるもの 15 例中には 3RL, 9RL，10RL， 11RR，16L の8例 (53\%) がある 即ち，排列の不規則 なるものに正常気導聴力示するのが最も多く，次化 や〉規則正しいもので，規則正しいものには認められな w.

第 2 項 気導聴力の低下と合気蜂棎の状態

1）気導聴力の低下と含気度

第 4 表より，気導㯖力低下を示するのは含気度甚大な るもの 7 例中 1LR，2RL，6L，13RL の全例 (100\%) であり，含気度の大なるむの9 例中 $6 \mathrm{R}, 7 \mathrm{RL}, 12 \mathrm{~L}$ ， $14 \mathrm{~L}, 15 \mathrm{RL}, 20 \mathrm{RL}$ の全例 (100\%) であり, 含気導な るもの 17 例冲 $2 \mathrm{RL}, 4 \mathrm{RL}, 8 \mathrm{RL}, 12 \mathrm{R}, 18 \mathrm{RL}$ の9例 (53\%) であり，含気度小なるむの7例中 $5 \mathrm{RL} ， 17 \mathrm{R}$ ， 19RL の 5 侧 $(71 \%)$ である. 即ち, 気尊聴力の低下は 含気度の大なるもの程多く認められる。

2）気尊㯖力の低下と胞膑の大いさ

気導聴力の低下を示するのは胞腔，大いさの大なるも の 1 例中 $1 R, 2 R, 4 L, 5 R L$ の 例 $(1 \%)$ であり, 胞 腔の大いさの中なるもの 10 例中 6RL, 7L, 8L, 12R の 5 例 (50\%) であり，胞腔の大いさの小なるもの13 例 中 8R, 13L, 14L, 15RL, 17R, 19RL, 19L のの9例 (69\%) であり，胞腔の混合性なるもの 10 例中 $1 \mathrm{~L}, 2 \mathrm{~L}$ ， 4R, 7R, 12L, 13R, 20RL, 21RL の全例 (100\%) であ る. 即ち，気導㯖力の低下は混合性のものに最も多く認 められ，次に胞腔の大いさの大なるむのと，小なるもの とであり，盷腔の大いさの大なるものに最わ少い，

3）気導聴力の低下と胞嵱の排列

気導㯖力の低下を示するのは，胞腔の排列の正しいる の9例中 1L, 6R, 7RL, 13L, 15RL, 19L, 21L の全例 


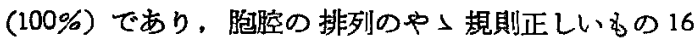
例中 $1 \mathrm{R}, 2 \mathrm{RL}, 4 \mathrm{R}, 6 \mathrm{~L}, 8 \mathrm{~L}, 12 \mathrm{RL}, 13 \mathrm{R}, 14 \mathrm{~L}, 18 \mathrm{RL}$, 20R, 21R の 14 例 (88\%) であり，胞腔の排列の 不規 則なる の 15 例中 4L, 5PL, 8R, 17R, 19R, 20L の 7 例 (47\%) である. 即る，気遒聴力の低下はいずれの胞 腔の排列状態にる約 $1 / 2$ 以上認められる.そして胞腔の 規則正しいるの程聴力の低下しているものが多い，

第3 項 気尊㯖力の低下振動数々含気蜂案の状態

1) 気導聴力の低下撷動数を含気度

第6表より，気㧱聴力低下を示す例を各々の振動数に

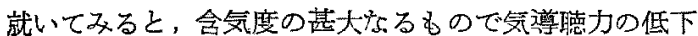
しているるの7 例の冬振勒数別聴力低下例数は夫々 0,0 , $0,7,5,7,7,5$ である. 即ち含気度の甚大なるものは 512 cps 以上の中，高音部に稀いて聪力の低下するものが多 い, 含気度の大なるもので気尊聴力の低下しているもの 9 例の各振動数別德力低下例数は夫々 $2,2,6,6,8,8,8$ で ある，即ち含気度大なる白のも512cps 以上の中, 高音 部に扎いて聴力の低下するすのか゚多い，含気度彻なるる ので気尊聴力の低下しているものタ例の备振動数別聴力 低下例数は夫々 $1,1,1,8,8,9,9,7$ である. 即ち，含気度 中なるものる512cps 以上の中, 高音部で聴力低下して いる，含気度小なるるので気尊㹔力の低下しているもの 5 例の 各振動数别㹔力低下例数は夫々 $0,2,1,4,5,4,4,4$ である。即ち，含気度小なるものも512cps 以上の中， 高音部で聴力低下しているものが多い。

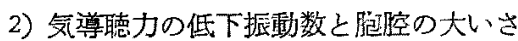

胞腔の大いさの大なるもので気㟊聴力の低下している

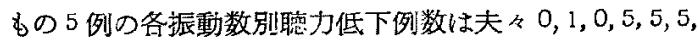
5,5である. 即占, 递腔の大なるものは $512 \mathrm{cps}$ 以上の 中，高音部で聴力の低下するものが多い，胞腔の大いさ の中なるすので気導聴力の低下しているすの 5 例の各振 動数別㹔力低下例数は夫々 $0,0,1,4,4,4,5,5$ である. 即

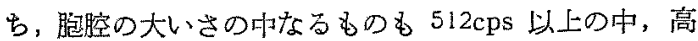
音部で眲力の低下しているものが多い，狍腔の大いさの

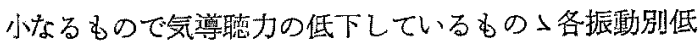
下例数は夫之 $1,1,1,6,6,9,8,5$ である。即占，胞腔の大 いさの小なるものも $512 \mathrm{cps}$ 以上の中，高音部で聴力低 下しているものが多い．胞腔の混合性なるもので気導聴 力の低下しているもの〉各振動数別低下゙例数は夫々0,

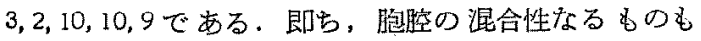
$512 \mathrm{cps}$ 以上の中, 高音部で㯖力の低下しているものが 多小。

\section{3) 気導聴力の低下振動数と胞数の排列}

胞腔の排列の規則正しいもので気尊聴力の低下してい るもの9 例の各振動数別聴力低下例数は夫々 $0,0,0,6$ ， 6,8,9,7である. 即ち，胞腔の排列の正しいるのは 512 cps 以上の中，高音部で䏇力の低下するものが多い，胞 腔の排列のや」規則正しいもので気尊德力の低下してい るもの 13 例の各振動数別咥力低下例数は夫々 $0,2,2,13$, 11，14，13，11である. 即ち，胞腔の排列のや」規則正し いもの8 512cps 以上の中, 高穴部で気動聴うjの低下し ているものが多い，胞膑の排列の不規則なるるので気尊 聪力の低下しているもの7例の各振動数別聴力低下例数 に夫々0,3,2,6,7,6,6,6である. 即ら，胞腔の排列の不 規則なるものも $512 \mathrm{cps}$ 以上の中，高音部で氮尊聴力の 低下しているものが多い。

第 2 節 含気蜂壘の状態々骨導㯖力

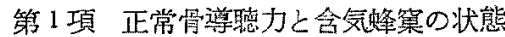

1) 合気度之正常骨煘唂力

第 4 表より，正常骨尊聴力（a）を示するのは含気䓕 大なるもの7例中 $13 R L$ の 2 例 (29\%) であり，大な るむの9例中 $14 \mathrm{~L}$ の1例 (11\%)であり, 又中なるも の 17 例中 $9 \mathrm{~L}, 11 \mathrm{~L}, 21 \mathrm{RL} の 4$ 例 $(24 \%)$ であり，小 なるむの7例中 17R，19L の2 例 (29\%) である。即

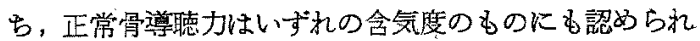
るが，含氮度甚大及び小なるるのに最す多く，中なるる。 のこれに次ぎ，含気度大なるものには最も少い：

2) 胞腔の大いさと正常骨導聴力

正常骨導聴力を示すわのは，胞腔の大なるるの7例中 にはなく，中なるもの10例中には，9L，11L の2 例: (20\%)があり，小なるもの13 例中には 13L, 14L, 17R の 4 例 (30\%) があり，胞察の混会性なるるの10例中心 は 13R, 21RL の3例 (30\%) がある. 即ち, 胞腔の大 いさ圤るものに正常骨導聴力示すものはないが， その他の大いさのむの〉20〜30\%に認るられる。

3) 胞腔の排列之正常骨頨㴔力

正常骨導㯖力を示すものは胞䆝の排列の規則正しいる の9例中 $13 \mathrm{~L}, 19 \mathrm{~L}, 21 \mathrm{~L} の 3$ 例 (33\%) であり，排列 のや>規則正しいもの16例虾 13R，14L，2IR の3例 (19\%) であり, 排列の不梘則なるもの15 例中 9L, 11

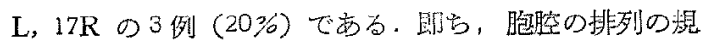

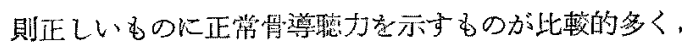
排列のや〉規則正しいるの及び不規則なるものにはや」 少、 
第 2 項 骨導聴力の低下と含気蜂窠の状態

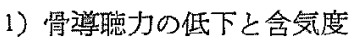

第 4 表より，骨導聴力低下を示するのは含気度旔大は るもの7例中，1RL，2RL，6L の 5 例 (71\%) であり， 大なるもの9例中, 6R，7RL，12L，15RL，20RL の8 例 (89\%) であり，中なるもの17例中 $3 \mathrm{RL} ， 4 \mathrm{RL}, 8$ L, 10L, 12R, 16L, 17L, 18RL の11例 (65\%) であり， 小なるすの7例中 $5 \mathrm{RL}, 9 \mathrm{R}, 10 \mathrm{R}, 19 \mathrm{R} の 5$ 例 (71\%) である. 即ち，骨導聴力の低下はいずれの含気度のもの 《も認められるが含気度の大なるすの最る多い。

2）骨導聴力の低下之胞腔の大いさ

骨尊聴力の低下を示するのは胞腔の大なるもの 7 例中 JR, 2R, 3RL，4L，5RL の全例 (100\%) であり，胞腔 の中なるもの10 例中 $6 \mathrm{RL}, 7 \mathrm{~L}, 8 \mathrm{~L}, 2 \mathrm{~L}, 10 \mathrm{~L}, 12 \mathrm{~L}$ の 7 例 (70\%) であり，小なるすの 13 例中 10R，15RL， $16 \mathrm{~L}, 17 \mathrm{~L}, 18 \mathrm{RL}, 19 \mathrm{R}$ の 8 例 (62\%) であり, 混合性 なるもの10例中 $1 \mathrm{~L}, 2 \mathrm{~L}, 4 \mathrm{R}, 7 \mathrm{R}, 12 \mathrm{~L} ， 20 \mathrm{RL}$ の 7 例 (70\%) である. 即古，胞腔の大いさの大なるものには 総て骨導聴力の 低下西示しその他の大いさの むの>約 2/3 亿認められる。

3）骨尊聴力の低下と胞控の排列

骨導慤力の低下を示するのは胞腔の排列の規則正しい

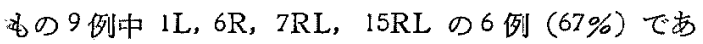
り，排列のや>規則正しいもの>16 例中 $1 \mathrm{R}, 2 \mathrm{RL}, 4$ R, 6L, 8L, 10L，12RL，17L，18RL, 20R の12 例 (75 \%)であり，排列の不覞則なるもの小15 例中 3RL，4 L, 5RL, 9R, 10R, 16L, 19R, 20L の10例 (67\%) で 西る. 即ら，いずれの排列状態のむのに括いても同じょ うな割合で骨遒聴力の低下を示して批り，胞腔の渄列の 状態と骨遒聴力低下との間には一定の関係がない。

第 3 項 骨導聴力の上昇之含気蜂笨の状態

1) 骨導聴力の上梨之含気度

第 5 裴上り骨導聴力の上杽を示すものは合気度甚大 なるもの及び大なるものにはなく，中なるもの11例中 3RL, 8R, 11R, 12R，16L，17L の7例 (64\%) であり， 小なるもの 5 例中 $5 \mathrm{R}, 10 \mathrm{R}$ の2例 $(40 \%)$ である. 即

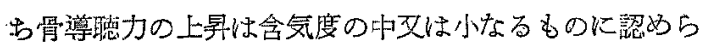
れ，甚大汉は大なるむのには認められない。

\section{2）骨尊衈力の上昇と胞腔の大いさ}

骨導聴力の上舁を示すものは胞腔の大いさの混合性の りのにはなく，胞腔の大なるもの7 例中 3RL, $5 \mathrm{R}$ の 3 例 (43\%) があり，胞腔の中なるるの10例的 $11 R, 12$ $\mathrm{R} の 2$ 例 (20\%) があり，胞腔の小をるの13 例中 8
R，10R，15L，17L の5例（38\%）がある. 即か，骨導

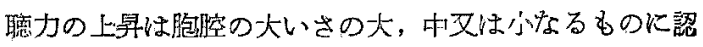
められ，混合性なるるのには認められない。

3）骨導聴力の上易之胞控の排列

骨遒眲力の上杽示するのは胞腔の排列の規則正しい もの9例中 $15 \mathrm{~L} の 1$ 例 (11\%) であり, 排列のや>規 則正しいもの 16 例中 $12 \mathrm{R}, 17 \mathrm{~L}$ の 2 例 (12\%) であり， 排列の不規則なるものでは 15 例中 $3 R L, 5 R,-8 R, 10 R$, $11 \mathrm{R}, 16 \mathrm{~L}$ の 例 (47\%) である. 即ち, 骨尊䏇力の上 昇は胞腔の排列の不䫏則なるるのに多く認められ，規則 正しいもの店や小規則正しいものには少い。

第 4 工真 骨導聴力の低下振動数上含気蜂篹の状態

1) 骨導聴力の低下振動数と含気度

第 5 表より，骨尊聴力低下を示す例の各振動数に就い てみると含気度甚大なるるので骨遒聴力の低下している bの 5 例の 各振動数別聴力低下例数は $1,1,2,3,2,3,3,5$ である．即ち，含気度甚大なるものは中，高音部にて骨 導聴力の低下しているものが多い，次に含気度大なるも ので骨尊聴力の低下しているもの8 例の各振動数別愊力 低下例数は 1,2,3，2,2,3,6.5 である. 即ら，含気度大な るものは $2048 \mathrm{cps}$ 以上の高音部にて骨導䏇力の低下し ているものが多い，含気度中なるもので骨導聴力低下す るもの 11 例の各振動数別岵力低下例数は夫々 $0,1,4,2$, $5,3,5,2$ である. 即ら, 含気度中なるるのは 256 4096 cps 間で骨導聴力の低下するるのが多い，含気尊小なる もので骨尊聴力低下するもの 5 例の各振動数別聴力低下 例数は夫々 $0,1,1,0,3,0,2,1$ である. 即ら, 含気度小な るものは 123〜8192cps の全音域仁亘つて骨導低下する 傾向がある。

故に骨導聴力の低下は含気度の大きいもの程高音部に て, 含気度の小さいものでは $64 \sim 8192 \mathrm{cps}$ の全音域に 亘つて低下する傾向がある。

2）骨導聴力の低下振動数と胞腔の大いさ

骨導䏇力低下を示与例を各振動数に就いてみると，胞 腔の大いさの大なるもので骨遒㯖力の低下しているもの 7 例の 备振動数別疅力低下例数は夫之 $0,0,2,2,3,1,4,2$ である. 即ち，胞腔の大いさの大なるものは 256〜8192 cps K亘って低下する傾向がある．胞腔の中なるもので 骨導聴力の低下しているすの7 例の各振動数別㯖力低下 例数は夫ぬ $2,4,5,2,2,1,3,2$ である. 即ら, 盷腔の大い さの中なるものは全音域洹つて低下する傾向がある。 胞腔の小なるもので骨導㯖力の低下しているるの8 例の 各振動数別聴力低下例数は夫々 $0,1,0,1,2,4,5,3$ であ 
る・即る，胞腔の大いさの小なるるのは特に $2048 \mathrm{cps}$ 以上の高音部で低下を示するのが多い，胞腔の混合性な るるので骨尊聴力の低下しているもの7 例の各振動数㓢 聴力低下例数は夫々 $0,0,3,3,4,3,4,6$ である. 即占, 胞 膑の大いさの混合性なるいのは 256〜8192cps 間で低下 しているものが多い

故に胞腔の大いさの大なるものと混合性のものでは 256〜8192cps 間で低下するものが多く，胞腔の中なる ののでは 64〜8192cps の全音域汇亘つて 低下するもの が多く, 胞腔の小なるむのでは $2048 \mathrm{cps}$ 以上の高音部 で低下しているものが多い。

3）骨導㯖力の低下振動数と胞腔の排列

胞腔の排列の規則正しいもので骨導㯖力の低下してい 万もの6 例の各振動数別㯖力低下例数快夫及 $1,2,3,2,2$, 4, 5,4である. 即も，胞腔の排列の規則正しいものは 64 〜8192cps 間但つて低下する傾问があるが特に 2048 cps 以上の高音部で低下しているすのが多い. 胞腔の排 列のや>規則正しいもので骨導聴力の低下しているもの 12 例の 各振動数別聴力低下例数は大《 $1,2,5,4,6,4,7$, 7である. 即ち，胞腔の排列のや規則正しいものは 64 8192cps 間に亘つて骨導聴力の低下を示すが 特に 中，高音部で低下するものが多い，腿腔の排列の不規な るもので骨導聴力の 低下しているもの 10 例の各振動数 别低下例数恃夫今 $0,1,2,1,4,1,4,2$ である. 即ち, 排列

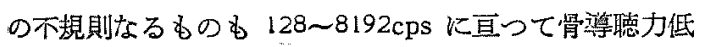
下しているが特に $1024 \mathrm{cps}$ と 4096 とで低下しているす のが多い。

故に骨導聴力の低下はいずれの排列状態に招いても存 するが，特に排列の規則正しいるのでは $2048 \mathrm{cps}$ 以上 の高音部に㨟いて，や>規則正しいものや、不規則なる ものに招いては $256 \mathrm{cps}$ 以上の中, 高部で低下するもの が多い.

第 5 項骨尊㯖力の上杽振動数之含気蜂䆞の状態

1) 骨導衈力口上算振動数と含気险

第 5 表より，骨導聴力上等を示す例を各振動数につい てみると，含気度の甚大なるものと，大なるものとには 骨導聴力が上易している例はなく，含気度の中なるもの で骨導聴力の上丮しているるの 7 例の各振動数別聴力上 昇例数は夫々 $0,0,1,0,2,2,1,1$ である. 即も，含気度中 なるものでは大体 256 81920 に亘つて骨導聴力の上 輩する傾向がある.含気度の小なるるので骨尊㯖力の上 杽しているるの 2 例の各振動数別㯖力上算例数は夫々 $0,0,0,0,0,0,1,1$ である. 即ち，含気度小なるものでは

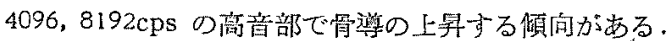

故に含気度中なるものでは 256〜8192cps の音场似亘 り，含気度小なるものでは 4096, 8192cps の高音部で骨 澊聴力の上昇する㥧向がある。

2) 骨等聴力の上开振㗢数之胞腔の大いさ

胞腔の大いさの混合性なるものとには骨導㭡力が上豕 しているものはなく，胞腔の大なるもの 3 例の各振動数 別聴力上昇例数は夫々 $0,0,1,0,1,0,1,0$ である. 即ち， 胞腔の大いさの大なるるのでは 256〜4096 問で聴力の上 梨する傾向がある.胞動の人いさの中なるるの2例の各 振動数別聴力上昇例数恃夫々 $0,0,0,0,0,1,1,0$ であり， 即ち胞腔の大いさの中なるものでは 2048,4096́cps 間の 高音域で恶力の上景する傾向がある．胞腔の大いさの小 なるもので骨導聴力の上昇しているもの 5 例の各振動数 別聪力上景例数は夫々 $0,0,0,0,1,1,0,3$ である. 即ち， 胞聜の大いさの小るるのでは 1024cps 以上の中, 高 音部で骨導㯖力の上昗与る傾向がある。

故に胞㓐の大いさの小るるものでは 1024cps 以上の 中, 高音部で, 胞腔の大いさの中なるものでは 2048, 4096cps で, 胞腔の大いさの大就る为のでは 256 4096 cps の音场に宣つて骨導聴力の上最する傾向がある.

3）骨導聴力の上戒振動数之胞腔の排列

胞腔の排列の規則正しいるので骨導恥力が上杽した1 例の上昇振動数は $8192 \mathrm{cps}$ であり, 排列のや>規則正 しいもの 2 例の上昇层動数は 4096, 8192cps である, そ して，排列の不規則なるもの7 例の各振怔数別德力上我 例数恃夫々 $0,0,1,0,2,2,1,1$ である. 即る, 胞腔の排列 の不規則なるものでは 256 8192cps 䦌に亘つて㬝力の 上杽する傾向がみられる。

故に胞腔の排列の規則正しいるのと，や>望則正しい ものとは高音域で聴力上昇を，不規則なるものでは 256 〜8192^ps の音域に亘つて腰力の上舁する傾问がある.

\section{第 4 章 総括並に考揬}

第 1 䬣 気導聴力之含気蜂窼との関倸

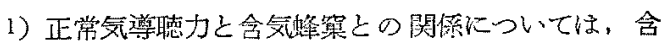

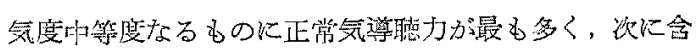

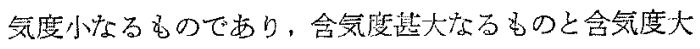
なるものとは正常気毞聴力を有するものが少く, 胞腔の 大いさでは中等度なるものに最も多く，次胞膑の大な るものであり，胞空の小なるものには少く，胞腔の混合 性なるむのには該当例がなく，胞腔の排列状態では胞空 の排列の不規則なるものに量も多く, 次にや小規則正し いものであり，排列の規則正しいものには該当例がなか 
つた.

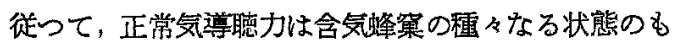
のに認められ, 正常気導㯖力は含気蜂巢の状態によつて 決定されないことが分る。

2）次に，気導聴力の低下を示するの」含気蜂笨の状 態については，含気度に関しては含気度の大なるすの程 低下を示するのが多く，胞腔の大いさについては胞腔の 混合性のものに㯖力の低下を示するのが最も多い. 次に 胞腔の大なるるのと小なるものであり，胞腔の中なるも のに最る少く, 胞腔の排列状態については胞腔の排列状 熊が規則正しいもの程多くあった。

㱜つて, 気導聴力の低下は含気蜂察の種々なる状態の

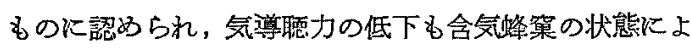
つて決定を下し得㣻い。

3）故に蜂菑の種々なる状態に気導聴力の正常なるの も, 低下しているものも共汇認められる点より蜂笨の状 態によつて気畠聴力を判定することはむつかしい。

このように含気䗋穼の状態によつて気導聴力を判定す ることが国難なのは恐らく生体では含気蜂巢の他に多く の伝音機構が気導㯖力に関与するので聴覚の個人差の起 因が直らに含気䗋棎の差異と点認され易いために起つた るのと推察される。

4）以上の成綘結果から含気蜂笨の状態によつて気導 㯖力を判定することは困難であるという結論を得たので あるが，乙かし含気蜂棎の状態と気導聴力との間には何 のような傾向があるが看ることができる，即ち，含気 度及び胞腔の大いさ共に吅等度で，胞腔の排列の不規則 なるものは気導㯖力は良好で合気度が大で胞腔の大いさ の混合性で胞腔の排列の規則正しいむの>気導聴力は低 下しているものが多くあるといらことである.

そこで，この含気蜂巢の気臫聴力との関保仙就いて考 察してみると，

先ず, 含気峰笨の含気度については，含気度の状態が 中等度なるるのは気導聴力が良く，大なるものは気導聴 力が瑟いといえる。

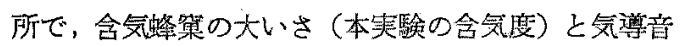
との関係济就いて存究したるのに原口, P.G. Macdonald の報告がある。

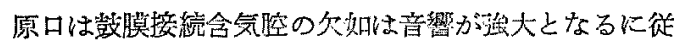

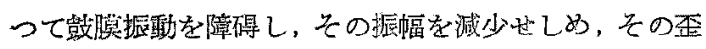
を增大せしめるのであり，この結果から蜂䆶は内耳や鼓 室を防音無響性に保台気導聴力の感音と忠実度とを良好 ならしめる作用があるとのべ， P.G. Macdonald”当模
型による实験を行い, 蜂菒は鼓臊振動に際し、鼓膜後方 に発生する防害音波を叹収し, 鼓膜が自由且つ在なしに 振勤し得るように作用して，気導聴力を良好ならしめる と述ペ，原口及び P.G. Macdonald は攺上同一結論を 報告している，従つて，原口，P.G. Macdonald の実験 結果は蜂窠 (主として乳樣洞) は気導妨慧音の吸収室で あることを提唱したことになる。

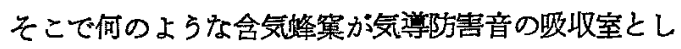
て㑑秀であるから゙問題になるが，この問題に対しては更 に原口及び P.G. Macdonald は臨床実験を行い次のよ うな結論を得ている。即ち，原口は実際に聴力検査を行 つた際に蜂寨の大なるるのに気導婹力の悪いものが多い 事実上り，玄の原因を頭蓋解剖に求め, 蜂巢の大さいる のに打いては乳様洞及び Aditusは周再の骨壁から突出 する蜂巢壁のために苵小之なり，従つて乳様洞接続㛔集 增多の効果が薑絡路 Aditus の狭小ななめに相殺され るために気導眲力の低下が起るのではないかと推察して いる.

P.G. Macdonald は人工鼓裳と含気蜂集との関係を 矿究して，蜂笨の発育の可良なるものつ方が気導聴力は 優秀であると述べている。

従って, 以上，原口， P.G. Macdonald の不究及び 本臨床実験等の結果を総合すると，次の上うな結果が得 られる. 即ち，P.G. Macdonald は模型実駼です臨床

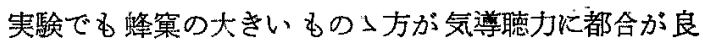
く，原口は模型実験では蜂㮤の大きいもの>方が気埒聴 力は良いが，臨床実験の結果では路巢の大きいもの入気

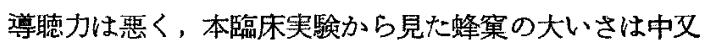
は小なるものが気導㯖力には都合がよいといら2つの異 つた結果が出たことになる。

この2つの暴つた成績結果を検討するにのぞみ先す問 題となることは含気蜂㮤の含気度か皆同一条件のもとに 計測判定されたかであるが，本実験の含気度はレ線像に よる蜂杲全体の平面的大いさ上り求るたるのであり，原

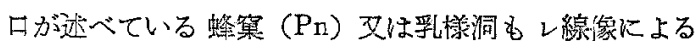
平面的大いさより，求めたるのであり，この点两者は同

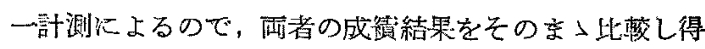
る.しかしこの方法によつてレ線像より蜂䆬の大いさ を判定することは峰案の立体性を無視することになり，

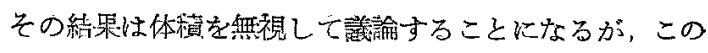
矛盾はレ線像測定方法そのものにも内含されているもの

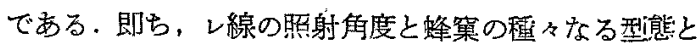
からレ線像の面積に变化をきたすからである。しかし， 
この問題も佐藤（寛）の研究によれば実際には含気腔の 大小は上線的に見た中耳蜂巢の発育度に活が平行してい るあのであり，従つてこれによつて，蜂杲の状態を判定 することはとれ程誤差を生じないと考兑られる。

しかして，原口，P.G. Macdonald 及び本実颐結果 には矛盾があるが，これ等の実験結果がいずれも正しい 事実だと肯定するならば, 含気峰菒の大小は正常耳の気 導聴力閑値附近の弱、気導音との間には殆んど直接関係 がないと考えた方がよいと推察するるのである。即ち，

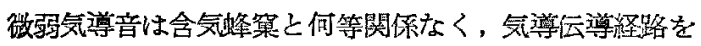
経て内耳達するものと考えるからである。

従つて, 含気䗋㮤之気導聴力䦨值とが何等かの関係が あるものとすれば，それは直接関係があるのではなく て，伝音経路のいずれかの部分と間接的に関倸があると 考えるものである. 即ち，含気峰巢の発育状態と気導伝 導経路の諸機官との形態的相互関倸が気導聴力に何らか の影響を与えるのではないかといつたような間接的なも のに原因を求めた方が理解しやすいので惊いいかと推察 寸るものである。

次胞腔の大いさと気導㯖との関保であるが、この関 伱を追求した文献が見当らないので本実験結果のみに就 いて見るに，気尊聴力は胞腔の大いさが中等度であるの が最る良く，混合性であるものが最も悪い。所で混合性

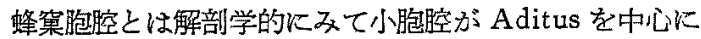
密在し，大胞腔が放の周辺に辺在しているものであり， このような大胞腔と小胞腔とが混在しているものが中胞 腔許りで形成されているむのより，気導聴力に之って何 故に不都合であるかは現在の所確かな推定ができないが 恐らく含気度の場合に述べたと同粎気尊間值之胞腔の大 いさとの間には直接的関係はなく，他の関接関係による のではないかと推察するるのである。

胞腔の排列之気導聴力以関しては胞腔の排列は不規則 なるの程気導聴力は良好であるが，この結果を求明する だけの論説がなく，こつに成績のみ記載するるのであ כ.

気導㯖力の低下しているるの振動数と蜂巢の状態を 比較してみると，含気度，胞腔の大いさ，胞腔の排列の いかえを問わず $512 \mathrm{cps}$ 以上の中，高音部で気導聴力の 低下してみるるのが多くあつた．即ら，いずれの型の蜂 菓も聴力の低下を示したことになり，含気蜂策の形態と

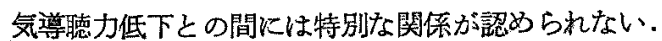

所で，合気度と聴力低下振動数との関係を逨べたもの そ先の P.G. Macdonald の報告がある. 即ち，人工鼓
膜を装用している患者に就て乳様洞入口部を清掃してか ら人工豉膜を用いると清掃前に比へて 64 8192cps の 各周波数仁亘り気導間値が 10 20db 上界することを観 察しているが，この実験法で性蜂菓の大小の他仿骨導聴 力の低下に上る筊導聴力の見掛上の上昇が考えられる が，この点炕ては述べられていない。

しかして，気尊聴力閾上の振動数と含気䗋集の状態と の間には明膫な関係がなく音珤の強驹が蜂窗の形態と最 る関保が梁いのではないかと考察するものである。

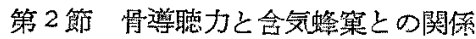

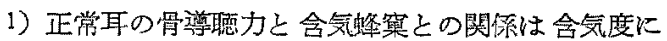

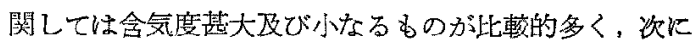
中なるもので，大なるものか㵊も少く，胞腔の大いさと 関しては，小及び混合性なるものが比較的多く, 次に中 なるもので，大なるものは少く，胞腔の排列状態関し ては排列の規則正しいるのに多く，や小規則正しいるの 区び不規則なるものには少くあつた。

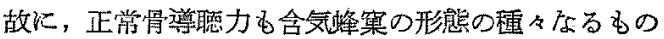
に認められ, 正常耳の骨導㯖力む含気蜂煲の形態のみに よつて影響されると決定されない。

2) そして, 骨尊聴力の低下を示するの〉含気峰窠の 状態は次の通りである.含気度に関しては含気度の大な るもの程多く，胞腔の大いさに関しても胞腔の大いざの 大なるものに多く，胞腔の排列に関しては胞腔の排列の ろっの形態に同じような割合に存在していた。

故に骨導聴力の低下も含気蜂案の種々なる状態に認め られ，含気蜂窠の状態によって骨導聴力の低下は沠定さ れない

3）次に骨尊聴力が上昇しているもの」含気峰窠の状 態は，含気度に関しては含気度の中文は小なるものに胞 腔の大いさに関しては胞腔の犬，中，小のいずれにる， 胞腔の排列に関してい胞腔の排列の不規則なるものに骨 導の上秭しているものが多くみられた。

故浲窂の種々なる 状態に骨導聴力の正常なるもの も，上舁しているものも，低下しているものも認められ ろ点上り蜂笨の状態に上つて骨導㯖力の影響されるるのを 判定することは困難である.

このように含気蜂笨の状態によつて骨道聴力を判定す ちことが困難な原因は気導聴力と含気峰案の状態を検討 した際に述べたと同倳含気蜂㑿のみが骨導聴力を決定す る唯一の条件でないことに起因するるのと思われる。し

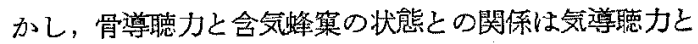
含気峰窧との関係より密接な関係にあるといらことは， 
骨導婹力の閾值測定は含気蜂窧を通じて行かれるが，気 尊聴力の測定は含気䗋窠を通さず成值の測定をし得る点 で推察される。

そこで，含気蛒巢のいかなる状態に骨導聴力の正常, 上景，低下が多くみられるかに就いて観察すると，

含気度中支は小にして，胞腔の大いさの中文は小なる ものに骨尊德力が正常又は上暴しているものが多く，含 気度及び㖹腔の大いさが大であるものに骨導聴力の低下 するわのが比較的多く，胞腔の排列状態々骨導聴力との 間には一定関係が見られないといら結果を得た。

しかして，含気峰巢の状態と骨導音との関係に就いて

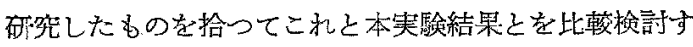
ると，

蜂策が骨導音飞対して音響絶緑效果を有するという論 説が大部分である。それに Pullen，原口，後藤，渑田等 の談がある. Pullen 林蜂笨胞の大いさの大小により骨 尊聴力に差異あることを提唱しているが，これに関して は後程包腔の大いさの頂で検討することにする．原口，

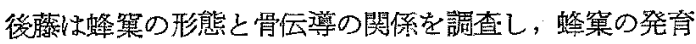
の不良のものでは骨伝尊は延長し䗋巢の発青可良なるす のでは骨遒は短縮すると述心，滰田は含気蜂䆞の発育の 抑制型は良好型上り骨導音に対する感受性が增進してい ると述べている.この原口, 後藤, 滝田の蜂窠の形態の 分類は先にも述べたさうに本実験の胞腔の含気度の分類 法とほ心゙同類方法であるので蜂巢の発育不良なるるのは 本実験の含気度小なるものであり，蜂笨の発育の良いむ のは含気度の大なるものであるとみてよい。しかして，

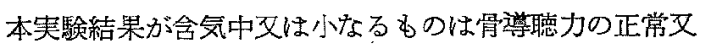
は上昇を示し，含気度人なるものは骨導聴力の低下を示 し, 合気度大なるものは骬導音の不良導体, 即方音の絶 縁休であり，含気度の小なるもの程骨導音の 良尊体即 ら，音の絶縁効果が少ないことを示したことになり，原 口, 後藤, 滝田等の臨床实験結果と全く一致している。 この原因を滝田は含気度の大きいものは小さいるのに較 へ構造的江空気室が大きく多くあり，これが骨伝尊音 を吸収し内耳に骨伝遒音が達し得ないようにできている ことを求めている。私も骨導間值附近の弱い骨導音に対 しては含気蜂窗を骨尊音の贿収体として考光る説に賛成 であるが，反対に含気䗋䆵は骨導音の共鳴体であると考 えても含気蜂笨の大いさと骨導聴力の関保を説明するこ そはできる。即ち骨導聴力は含気蜂䆞の吸収音を聴取し たものではなく，含気蜂窠の共鳴音を聴取したものであ ると考学るならば，大きい含気蜂笨の共鳴には大きな音
圧が必要であり，小さい含気蜂笨の共洍には小さい音圧 でたり，従つて，大きい含気䗋巢は骨導聴力が悪く，小 さい含気蛒笨は骨導聴力が良いといえるからである。

以上の含気䗋䆵の音吸收説及び共鳴説のいずれによつ

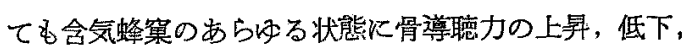
正常がみられる点を究明することはできない．それで含 気蜂窠は骨導聴力に刘しては閒接的存在であり, 直接的 には側頭骨の骨振動の砳究で結諭を得たように骨導音は 特に固い骨質部を通つて直接内耳に達するもので骨導音 の不良導体である含気䗋巢を態々通過して内耳に行くこ とはあるまいと考えるものである。

次泡腔の排列上骨導缌力に関しては，耐者間に余り 明膫な美異を示さず，骨導婹力之含気䗋菑の排列状態と の間には含気度の大いさや，胞腔の大いさ程密接な関係 が少いことを示したと誢めるものである。

4）骨尊㯖力の 低下又は上昇の振動数之䗋巢の 状態を 比烄した結果は含気度に関しては骨尊聴力の低下は含気 度の大きいるの程高音で低下し，上昇は含気度の中なる ものは 64 8192 cps の全音域に亘り.含気度小なるも のは 4096, 81922ps の高音部であり，含気度の大なる あのにはその例がない，従つて，含気度の大なるものと 含気度の小なるものは高音 4096, 8192cps で骨導聴力の 低下文は上暑をきたし，他の含気度の状態失種々なる振 動数に括いて聴力の上昇又は低下をきたしていた。

しかして, 含気度と骨導聴力の低下, 上第振動数に就 いて検討するに原口は骨導可聴闒值を 49-A オージオ メーターを使用して測定し，抑制型ば良形型に比べて $256 \sim 2048 \mathrm{cps}$ 間の音域に沶いて 4 8db の比較的良聴 を証明することができたと述べている。このように含気 度の大小に上り聴力の但下攵は上算が全音域に亘つて起 るか，それとも高音部においてのみ起るのかいずれに真 実性があるか性予測することができない，しかし，含気 度の大小に上り骨導㯖力の振動数に変化があるように推 測される。

次泡胞腔の大いさと骨尊聴力の低下又は上昇の振動数 との関係を見るに, 聴力の低下は胞腔の大なるるの, 中 なるるの，混合性なるむのに拈いて 64〜8192cps の全 音域炡つているが，大なるものに拈いては特に 4096 cps で低下する傾向があり，小なるものに执いては特に $2048 \mathrm{cps}$ 以上の高音部で低下する傾向が明らかである。 又㯖力の上昇は胞腔の大いさの大なるものは 256 8192 $\mathrm{cps}$ 間の全域に亘り，小なるものでは $2048 \mathrm{cps}$ 以上の 高音部で上笔する傾向があるが，その他の大いさのもの 


\section{には上氞例がない}

しかして，胞腔の大いさと骨導聴力とを論じたものに Pullen の業樍がある. Pullen は大細胞性の乳㥞突起の 骨振動と小細胞性の乳粎突起の骨振動之の間には 25

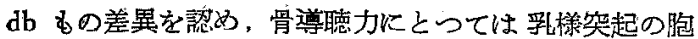
腔の大いさは有力なる骨尊音の絶縁体で大細胞は小細胞 より骨尊音の絶縁効果が大であると述べているが，その 25db．の低下がいかなる 振動数においてであるか明瞭で はない，所で本実驗では胞腔の大なるものに和いて骨尊

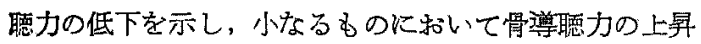
を示するのが多くあつた点で Pullen の説と一致してい ๖.

次に Pullen が大胞腔性のbのでは小胞腔性のものK 較へて骨尊聴力が $25 \mathrm{db}$ b低下していると述べた点につ き本実験成續によつて検討すると，胞腔の大なるもの〉 1R, 2R, 3RL, 4L, 5RL の7例と小なるもの〉 8R, 10 $\mathrm{R}, 13 \mathrm{~L}, 14 \mathrm{~L}, 15 \mathrm{RL}, 16 \mathrm{~L}, 17 \mathrm{RL}, 18 \mathrm{RL}, 19 \mathrm{RL}$ の 13 例との各振動数の骨導聴力值の算術平均値は, 64 8192 cps 08 振動数に尗いて胞腔の大なる 手のは夫々 46 , $56,51,53,44,36,33.8 \mathrm{db}$ であり, 胞空の小なるるのは 夫ネ $45,56,50,50,42,35,32.3 \mathrm{db}$ であり, いずれの 振動数において子坨腔の大なる 6の〉平均值の方が小さ く，骨尊㯖力が低下していることを示しているが，しか しその差は 64cps で $1 \mathrm{db}, 128 \mathrm{cps}$ で $0 \mathrm{db}, 256 \mathrm{cps} 1 \mathrm{db}$, $512 \mathrm{cps}, 3 \mathrm{db}, 1024 \mathrm{cps} 2 \mathrm{db}, 2048 \mathrm{cps} 1 \mathrm{db}, 4096 \mathrm{cps} 1 \mathrm{db}$, 8192eps 5db で Pullen のいらような胞腔の大小たより $25 \mathrm{db}$ の骨䊒聴力差があるといらことは正常耳におけする

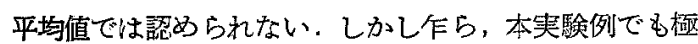
端な例を選出して，その䏇力差を求奶れば $64 \mathrm{cps} 10 \mathrm{db}$ ， $128 \mathrm{cps}, 15 \mathrm{db}, 256 \mathrm{cps} 15 \mathrm{db}$, 512cps $15 \mathrm{db}, 1024 \mathrm{cps} 35$ $\mathrm{db}, 2048 \mathrm{cps} 35 \mathrm{db}, 4096 \mathrm{cps} 25 \mathrm{db}, 8192 \mathrm{cps} 25 \mathrm{db}$ とな り，胞腔の大小により全音域に亘つていえば 10〜35db の畗力差があり, Pullen のいら 25db の差名誌められ ないこと歹ない。

しかして，その差は 1024cps 以上の高音部にて特に 明瞭訫認められる. 従つて，一般的には Pullen がいら ように大胞腔と小胞腔との用には $25 \mathrm{db}$ むの差が認めら れない

又本実験では胞腔の大いさの大なるものは聴力の上暴 b低下b共に 64 8192 cps の全音域に亘つており, 盷 腔の小なるものでは $2048 \mathrm{cps}$ 以上の 高音部に上昇及び 低下を示す傾向があり，このように上最又は低下を同一 振動数で示すといらことは骨導聴力が単に胞腔の大小に
よつて決定されないことを襄付けたるのと思う．又胞膑

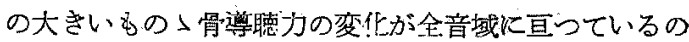
に小なるものが $2048 \mathrm{cps}$ 以上の高音部で変低がある点 に就いてはこのよらな結果が出たことのみる記すにとよ ぬる.

次に骨導聴力の低下攵は上昇しているもの>振動数之 胞腔の排列之の関係を見るに，恥力の低下はいず犰の排 列状態にる見られ，その聴力の低下を示可振動数を芫る と, 排列の規則正しいるのは 2048 2ps 以上の高音部で， 排列のや〉規則正しいものと，不規則なるものは256 cps 以上の広い音域に亘つており，恥力の上算学する の〉振動数は排列の摆則正しいものと, 中>规則正しい

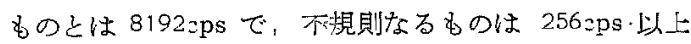
の広い音域に亘つている傾向がある。

しかして，胞腔の排列状態と骨竴聴力との関係老研究 した報告がないこと及び本契驗の上鼠例数が非常に少な い点から，排列之骨導聴力との関係を醮実に結諭つける ことはできない，しかし，本英験の結果から椎察すると

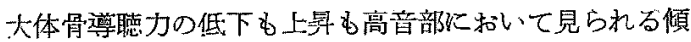
向があり，腸腔の排列状態と骨導聴力の振動数との間に は余り梁い関係がないよらである。

以上の成績結果より含気䗋巢上骨導聴力の振動数との 間には余り明膫なる関係が見出せない.そして, Pullen

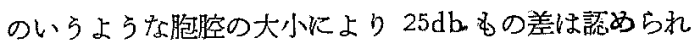
なかつた，即ら，正常耳の骨振導においては胞腔の大き いるのは小さいるのより $5 \mathrm{db}$ 前後の聴力低下を示して いた。

\section{第5章 結 論}

含気䗋笨の状態をゾントンタルプ氏法による撮影した ものと正常耳の気導及び骨尊㯖力とを比較検討した結 果.

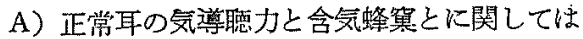

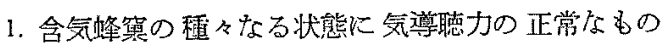
も，低下（正常なむのより 5〜10db 低下しているもの）

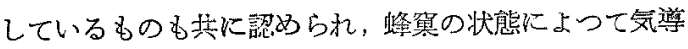

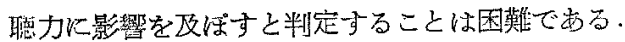

2. 含気峰兾の状態と気尊衈力との間には何のような 傾问があるかを調べた結果は含気蜂巢の壮熊が含気度及 び胞膑の大いさが共に中等度で胞腔の排列の不規則なる わのは気澊聴力は良好で，含気度が大で胞腔の大いさが 混合性で，胞腔の排列の規則正しいるの〉気導㯖力は低 下しているものが多くあった。

3. 含気蜂案と正常耳の気導閵拊近の聪力との間に 
関係があるものとすれば，それは含気蜂巢の状態が融接 気導聴力に関係するのではなくて，含気蜂窝の発育状態 々気尊伝尊経路上の諸㙨官との形態的相互関係が気導聴 力に及ぼす間接的関係によるものではないかと推論され る.

4. 気導聴力の低下 $(5 \sim 10 \mathrm{db})$ しているるの〉振動数 と蜂寓の状態とを比較するに両者間には明膫なる関係が 見出されなかつた。

B）正常耳の骨導聴力と含気蜂杲とに関しては

1. 含気蜂笨の種々なる状態に，骨尊聴力の正常なるの

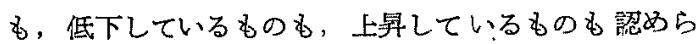
れ，蜂巢の状態によつて骨導㯖力に影響を及ぼすと明確 飞判定することは困難である．

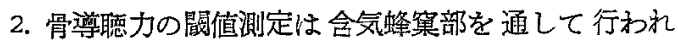
るが，気尊㯖力の測定は含気䗋䆵を通さず直接闒值の測 定をし得る点からして, 骨導聴力と合気䗋巢の状態との 関保は気導聴力と含気蜂窤との関保上り密接な関係にあ ると推察される。

3. 含気蜂巢の状態と骨尊聴力との.関倸は 含気度中又

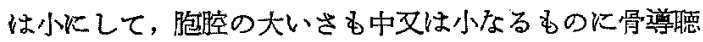
力が正常又は上昇しているものが多く，含気度及び胞腔 の大であるものと骨導聴力の低下するものが多く，胞腔 の排列状態と骨導聴力との間には一定関保が見られない といら傾向がある。

4. 含気蜂杲の状態之骨尊聴力との関係結果からして, 合気蜂蓂が骨導音に対して音響絶縁効果を有するという Pullen, 原口, 後藤, 滰田等の論説に賛意を示すもので あるが，このような不良導体である含気蜂算を通過して 骨尊音が内耳火達するということは不可解なことではな いかと推察するものである，即ち，骨伝導は含気蜂集を 構築している所の骨導音の良導体である固い骨質部を伝 つて直接内耳に達するものではないかと考えるむのであ
る.

5. 含気蜂窼之 骨導聴力の 振動数之の間飞は余り明嘹 なる関係が見出せなからた。そして，Pullen のいうよ らな胞察の大いさの大小により $25 \mathrm{db}$ も差は認められ なかつた，胞膑の大きいるのは小さいるのより平均 $5 \mathrm{db}$ 前後の骨導聴力低下を示すと過ぎない。

\section{参考文 献}

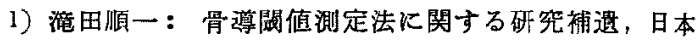
耳细咽会報，62 巻，7号，144，(昭 34)。2）原口静彦: 中耳 Pneumatisation と聴覚との関係飞ついての研究，

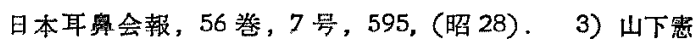

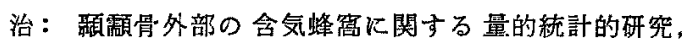
日本耳率会報, 41 巻, 8 号, 981, (昭 10)。4)山下害

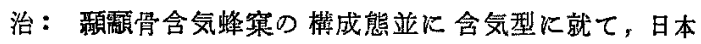
耳鼠会報，41巻，8号，1002（昭 10). 5) 大和田健 次郎：正常者骨導最小可聴值の変動, 耳楀咽㬋科, 29 巻, 1 号, 9, (昭 32). 6) Pullen, E.M.: The Insulation Effect of the Mastoid Process on Bone $\mathrm{C}_{0}$ nduction. New York state Jour. Med. 50 : 301, 1950. 7) Phiiip G, Macdonald, M,D.: Functioning of the aircell system of the mastoid Process in Audition. Archives of otolary 49:5, 1949.

本論文の要旨は第127回日本耳奥咽喉科学会 東海地方会（昭 26.11）；第 128 回日本耳鼠咽䒨 科学会東海地方会（昭 27.1）に沶いて発表した。

擱筆に当り終始御恩䉆なる御指導を睗り且つ 御校閲を忝うした恩師後藤修二教授に深甚なる 謝意を表すると共に御援助下さつた三宅弘助教 授に感媩するものである。

（原稿到着 $=$ 昭和 34.10 .14 日） 